\title{
Arsenic in Ground Water in Sanilac County, Michigan
}

\section{INTRODUCTION}

Previous studies of ground-water resources in Michigan by the Michigan Department of Community Health $(\mathrm{MDCH})$, the Michigan Department of Environmental Quality (MDEQ), and the U.S. Geological Survey (USGS) indicate that in several counties in the southeastern part of the State the concentrations of arsenic in ground water may exceed the U.S.

Environmental Protection Agency (USEPA) maximum contaminant level (MCL) of 50 micrograms per liter $[\mu \mathrm{g} / \mathrm{L}]$. This MCL was established in 1986. The Safe Drinking Water Act, as amended in 1996, requires USEPA to revise this standard in 2000. In June 2000 , the USEPA proposed a revised MCL of $5 \mu \mathrm{g} / \mathrm{L}$.

In 1996, the USGS, in cooperation with the MDEQ and the Health Departments of Genesee, Huron, Lapeer, Livingston, Oakland, Sanilac, Shiawassee, Tuscola and Washtenaw counties, began a study of the factors controlling arsenic occurrence and concentrations in ground water in southeastern Michigan. This study is one of four USGS Drinking Water Initiative projects throughout the United States.

\section{SOURCE OF ARSENIC}

Arsenic is a common, naturallyoccurring element in the Earth's crust. Arsenic in ground water is often a result of arsenic-bearing minerals dissolving naturally over time. Historical wellwater data for southeastern Michigan indicated that where arsenic concentrations of ground water were elevated, wells were commonly, though not exclusively, completed in the Marshall Sandstone. The Marshall Sandstone is a fluvial to marginal marine geologic unit that is present below glacial materials in part of the study area (fig. 1). Drinking-water wells in the study area often draw water from one or more additional geologic units - the Saginaw Formation, the

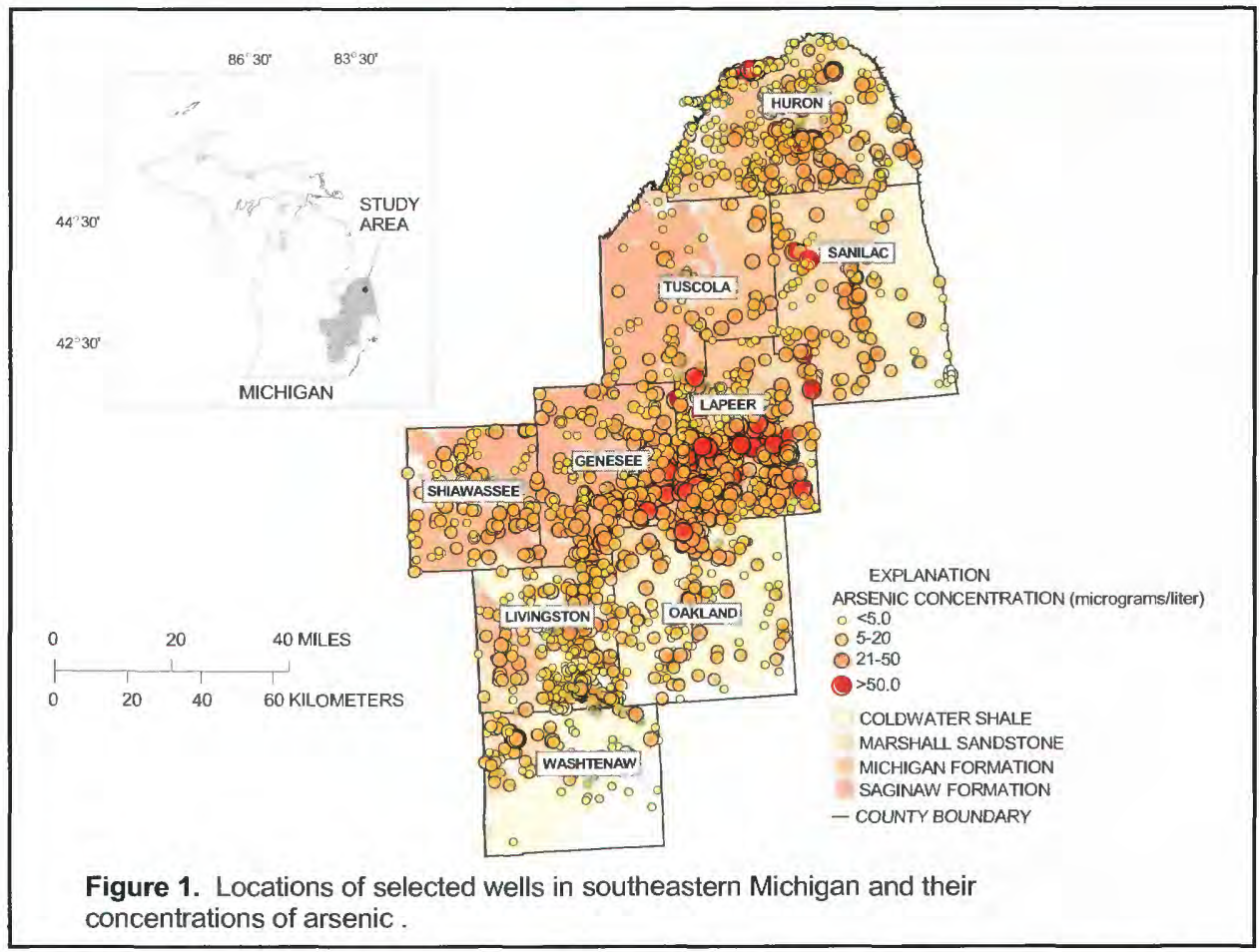

Michigan Formation, or the Coldwater Shale (fig. 1), as well as from the glacial materials that overlie these bedrock units. Figure 1 shows the arsenic concentration of 3,022 wells in the study area. Data for figure 1 were taken from recent and historical USGS records, as well as from MDEQ records of well-water analyses for domestic and public water supplies from 1997 to 1999 . The USGS collected water samples from 76 domestic and public drinking-water wells in southeastern Michigan as part of this study. The wells were chosen to represent various aquifers in the study area and to avoid any possible source of human contamination. The highest arsenic concentration measured by the USGS $(220 \mu \mathrm{g} / \mathrm{L})$ occurred in a well drawing water from the Marshall Sandstone. However, the USGS measured arsenic concentrations exceeding the current USEPA standard of $50 \mu \mathrm{g} / \mathrm{L}$ in well water from all aquifer units except the glacial sand and gravel deposits, and arsenic concentrations equal to or exceeding $40 \mu \mathrm{g} / \mathrm{L}$ were measured in wells completed in glacial sediments in three counties.

\section{DISTRIBUTION OF ARSENIC IN GROUND WATER IN SANILAC COUNTY}

Information on ground-water arsenic concentrations in Sanilac County was available from the MDEQ, the USGS, and the county. The USGS sampled six drinking water wells in Sanilac County as part of this study. The 116 analyses shown in figure 2 represent recent (1997 or later) MDEQ wellwater analyses for total arsenic, as well as USGS analyses for total or dissolved arsenic. Of these, 3 ( 2.6 percent) exceeded the USEPA standard of $50 \mu \mathrm{g} / \mathrm{L}$ (table 1). Sixty-seven of the 116 wells ( 57.8 percent) had arsenic concentrations less than or equal to $10 \mu \mathrm{g} / \mathrm{L}$, and 54 wells had arsenic concentrations less than $5 \mu \mathrm{g} / \mathrm{L}$. Welldrilling records were available for 48 wells. The highest arsenic concentration recorded for a well of known construction was $77.2 \mu \mathrm{g} / \mathrm{L}$ for a well in Evergreen Township completed in the Marshall Sandstone at a depth of $195 \mathrm{ft}$. The second highest concentration $(49 \mu \mathrm{g} / \mathrm{L})$ was recorded in Washington Township in a well completed at $50 \mathrm{ft}$. depth in glacial materials. 


\section{HEALTH EFFECTS OF ARSENIC}

The Agency for Toxic Substances and Disease Registry (ATSDR, 1998)

Toxicological Profile for arsenic describes some possible health effects of arsenic exposure. Consumption of arsenic doses greater than $60,000 \mu \mathrm{g} / \mathrm{L}$ in food or water can be lethal (ATSDR, 1998). Doses between 300 and $30,000 \mu \mathrm{g} / \mathrm{L}$ may cause stomach pain, nausea, vomiting or diarrhea (ATSDR, 1998). Long-term exposure to arsenic may produce other effects. Arsenic is classified as a known human carcinogen by the USEPA, and it has been linked to skin, bladder, lung and prostate cancer. In addition, non-cancer effects of long-term exposure may include darkening and thickening of the skin (especially on the palms of the hands, the soles of the feet, and the torso) as well as numbness of the feet and hands, anemia or cardiovascular changes. The concentrations of arsenic that result in these long-term effects have not been clearly established.

\section{FOR MORE INFORMATION}

For more information on arsenic in drinking water in Sanilac County, contact the Sanilac County Health Department, 171 Dawson St., Sandusky, MI, 48471 (phone: 810-648-2150). For more information on arsenic in drinking water in Michigan, contact the Michigan Department of Environmental Quality, Drinking Water and Radiological Protection Division, 3423 N. Martin Luther King Jr. Blvd., P.O. Box 30195, Lansing, MI, 48909 (phone: 517-3359218) or contact the Michigan Department of Community Health, Division of Environmental Epidemiology, 3423 N. Martin Luther King Jr. Blvd., Lansing, MI 48909. MDCH can be reached toll free by calling 1-800-6486942. MDCH can also be reached by calling 517-335-8350.

\section{REFERENCE}

Agency for Toxic Substances and Disease Registry, 1998, Toxicological Profile for Arsenic, Atlanta, GA: Agency for Toxic Substances and Disease Registry, Division of Toxicology, $349 \mathrm{p}$.

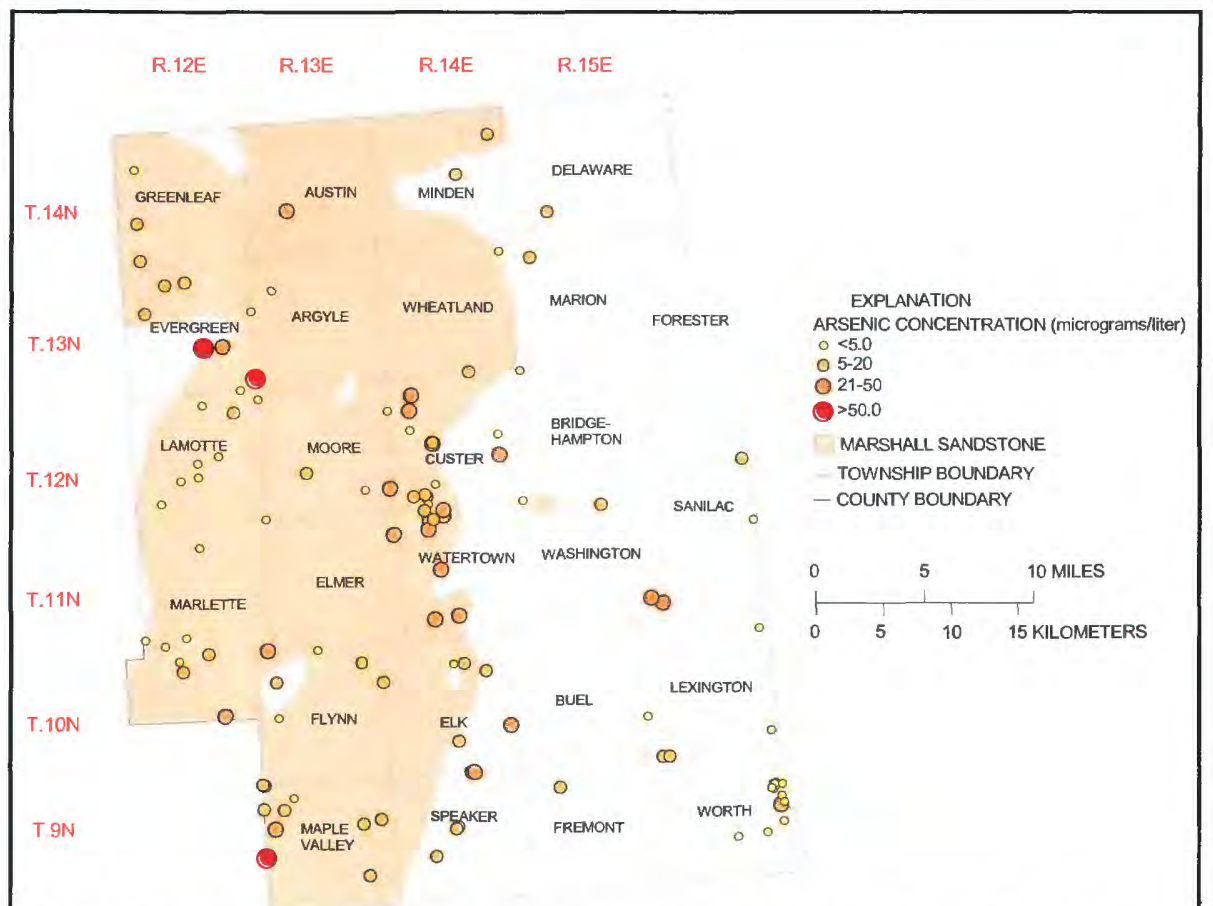

Figure 2. Location of wells and their concentration of arsenic, Sanilac County, Michigan.

Table 1. Arsenic summary by township. $[\mu \mathrm{g} / \mathrm{L}=$ micrograms per liter; detection limit $=1 \mu \mathrm{g} / \mathrm{L}]$

\begin{tabular}{|c|c|c|c|c|}
\hline Township & $\begin{array}{l}\text { Number of } \\
\text { wells }\end{array}$ & $\begin{array}{c}\text { Median Arsenic } \\
\text { Concentration }(\mu g / L)\end{array}$ & Percent $<5 \mu g / L(\%)$ & Percent $>50 \mu g / L(\%)$ \\
\hline Argyle & 1 & 1.6 & 100.0 & 0.0 \\
\hline Austin & 1 & 28.0 & 0.0 & 0.0 \\
\hline Bridge-Hampton & 1 & 0.0 & 100.0 & 0.0 \\
\hline Custer & 13 & 10.6 & 38.5 & 0.0 \\
\hline Delaware & 1 & 9.8 & 0.0 & 0.0 \\
\hline Elk & 5 & 14.0 & 20.0 & 0.0 \\
\hline Elmer & 1 & 29.6 & 0.0 & 0.0 \\
\hline Evergreen & 8 & 23.5 & 12.5 & 25.0 \\
\hline Flynn & 5 & 5.0 & 40.0 & 0.0 \\
\hline Fremont & 1 & 6.8 & 0.0 & 0.0 \\
\hline Greenleaf & 3 & 5.1 & 33.3 & 0.0 \\
\hline Lamotte & 9 & 0.0 & 88.9 & 0.0 \\
\hline Lexington & 5 & 4.6 & 60.0 & 0.0 \\
\hline Maple Valley & 10 & 14.8 & 10.0 & 10.0 \\
\hline Marion & 1 & 7.2 & 0.0 & 0.0 \\
\hline Marlette & 9 & 2.4 & 33.3 & 0.0 \\
\hline Minden & 2 & 12.5 & 0.0 & 0.0 \\
\hline Moore & 6 & 1.9 & 66.7 & 0.0 \\
\hline Sanilac & 2 & 7.2 & 50.0 & 0.0 \\
\hline Speaker & 5 & 9.4 & 0.0 & 0.0 \\
\hline Washington & 3 & 26.0 & 0.0 & 0.0 \\
\hline Watertown & 9 & 26.0 & 0.0 & 0.0 \\
\hline Wheatland & 2 & 6.8 & 50.0 & 0.0 \\
\hline Worth & 13 & 0.0 & 92.3 & 0.0 \\
\hline Total & 116 & 7.6 & 46.5 & 2.6 \\
\hline
\end{tabular}

Sheridan K. Haack and Cynthia M. Rachol

For more information contact

U.S. Geological Survey

6520 Mercantile Way, Suite 5

Lansing, Michigan 48911

Telephone:517-887-8903

Fax: 517-887-8937

http://mi.water.usgs.gov 